\title{
PENERAPAN BUKU AL-FATIH DALAM MENINGKATKAN KEMAHIRAN MEMBACA KITAB KUNING DI PONDOK PESANTREN MADINATUL ILMI DDI SIAPO TOLI-TOLI
}

\author{
Titin Fatimah, Mahfudhoh \\ Institut Agama Islam Negeri Palu, Indonesia \\ Jl. Diponegoro No. 23, Kec: Palu Barat, Kota Palu, Sulawesi Tengah, 94221, Indonesia \\ Corresponding E-mail: titindeden@gmail.com
}

\begin{abstract}
This study aims to find out how the application of the Al-Fatih Book in improving reading skills of the yellow book; and to know the steps of its application in the learning process. The research approach used is descriptive qualitative. techniques in data collection through interviews, observation, and documentation. The results of the study show that the application of the Al-Fatih Book is almost the same as other fast methods of reading the yellow book, only in its application, the Al-Fatih book uses three volumes of books, namely: the Nahwu Al-Fatih book, the Tașrif book and the Al-Fatih practice book. munīr. while in increasing the reading skills of the students, it can be seen from the value of the practice and practice of the students in the ability or proficiency in reading the yellow book.
\end{abstract}

\section{Key words: Reading Skills, Al-Fatih Books, Classical Books}

\begin{abstract}
Abstrak
Penelitian ini bertujuan untuk mengetahui bagaimana penerapan Buku Al-fatih dalam meningkatkan kemahiran membaca kitab kuning; serta untuk Mengetahui langkah-langkah penerapannya di dalam proses pembelajaran. Pendekatan penelitian yang digunakan ialah kualitatif deskriptif. teknik dalam pengumpulan data melalui Wawancara, observasi, dan dokumentasi. Hasil penelitian menunjukan bahwa pada penerapan Buku Al-fatih ini hampir sama dengan metode-metode cepat baca kitab kuning lainnya hanya saja dalam penerapaannya buku Al-fatih ini menggunakan Tiga jilid buku yaitu: buku Nahwu Al-fatih, buku Tașrif dan buku praktek Al-munīr. sedangkan dalam peningkatan kemahiran membaca para santri dapat dilihat dari nilai latihan dan praktek para santri dalam kemampuan atau kemahiran membaca kitab kuning.
\end{abstract}

Kata Kunci: Kemahiran Membaca, Buku Al-Fatih, Kitab Kuning. 


\section{PENDAHULUAN}

Perkembangan IPTEK hari ini memiliki dampak yang sangat besar terhadap proses Pendidikan dan tujuan Pendidikan, Termasuk juga di dalamnya lembaga pondok pesantren. Dalam proses belajar-mengajar pondok pesantren tetap mempertahankan budaya membaca kitab kelasik, dikarenakan tidak sedikit sumbersumber ilmu-ilmu fiqih, Aqidah Ahlak, AlHadits, Tafsir, dan ilmu-ilmu agama lainnya itu semua menggunakan bahasa Arab, bahkan ilmu-ilmu pengetahuan di bidang teknik, ilmu-ilmu murni dan ekonomi piskologi maupun seni dan lainnya juga ada yang bersumber dari buku-buku bahasa Arab.

Maka untuk mewujudkan kemampuan kemahiran membaca kitabkitab kelasik atau lebih populer disebut kitab kuning, maka dalam sistem pengajaran lembaga perlu menerapkan metode-metode khusus dalam memahamkan dan mengajarkan santri secara cepat dan efesien.

Melihat penjelasan di atas yang begitu urgennya maka peran pengajar sangatlah penting. Dari segi kompetensi pengajar harus mempunyai kompetensi untuk memberikan pemahaman kepada santrinya. Disamping itu, penyajian materi yang sesuai dengan kemampuan dan

\footnotetext{
Azhar Arsyad,Suatu Psikodinamik Terhadap Metodelogi Bahasa Asing Inofatif(Jakarta:Al-Quswa, 1989), 1
}

tingkatannya harus benar-benar diperhatikan. Dari beberapa dimensi yang perlu diperhatikan di atas hal yang menjadi perhatian lebih setelah itu adalah penerapan metode dalam pembelajaran bahasa Arab /kitab kuning.

Metode mengajar merupakan hal yang wajib dimiliki oleh setiap pengajar, guna untuk mempermudah dan mensukseskan proses pembelajaran. Bahkan Azhar Arsyad menyatakan bahwa" metode lebih penting dari subtansi atau materi". 1

Pada hakikatnya untuk meningkatkan pengajaran dan pembelajaran Bahasa Arab atau membaca kitab kuning diperlukan jumlah formulasi baru melalui berbagai perkembangan. Misalnya, mengutamakan meningkatkan kemahiran membaca terhadap para santri. Hal ini serupa di pondok pesantren Madinatul Ilmi DDI Siapo Toli-Toli. Di pesantren ini mengalami penurunan dalam memahami pembelajaran membaca kitab kuning atau bahasa Arab, sehingga Ustadz yang mengajarkan Bahasa Arab dan kitab kuning memberikan formulasian baru berupa Buku Pembelajaran lain yang masih samar di dengar oleh khalayak atau orang lain. 
Al Bariq : Jurnal Pendidikan Bahasa Arab, 2, (2), 2021,

\section{PEMBAHASAN}

\section{A. Penerapan Buku Al-Fatih}

Kata penerapan dalam kamus besar bahasa indonesia (KBBI) berasal dari kata "terap". Yang berarti prihal "mempraktekkan".2 Dapat disimpulkan bahwa penerapan adalah mempraktekkan segala teori yang ada guna untuk mencapai suatu tujuan yang diinginkan.

Menurut W. J. S. Poerwadarminta bahwa penerapan metode adalah terdiri dari dua rangakaian kata, dari kata dasar terap dan metode. penerapan berarti prihal mempraktekan, sedangkan kata metode adalah suatu cara yamg ditempuh dengan teratur, sistematis, terencana dan terpikir secara baik-baik untuk mencapai suatu maksud atau tujuan tertentu. ${ }^{3}$

Dalam menerapkan dan merancang suatu metode yang bisa tepat pada sasarannya adalah suatu hal yang menjadi keinginan para pengajar di pondok pesantren. Jadi, dalam mewujudkan semua itu perlu wawasan dan keseriusan serta tanpa pantang menyerah dalam kondisi apapun.

Penerapan metode adalah hal yang urgen karena termasuk jalan tercapainya sesuatu yang kita harapkan, dan perlu

\footnotetext{
2 Departemen Pendidikan dan kebudayaanR.I, Kamus Besar Bahasa Indonesia. (Cet.III, Jakarta: Balai Pustaka,1994)935
}

${ }^{3}$ W.J.S. poerwadarminta, Kamus Umum Bahasa Indonesia, (Jakarta: Balai Pustaka, 1993) 105 dan 649. kerjasama antara Ustadz dan santri dalam mendukung suatu penerapan metode tersebut. Penerapan metode pengajaran tidak akan berjalan dengan efektif dan efesien sebagai media pengantar materi pengajaran bila penerapannya tidak didasari dengan pengetahuan yang memadai tentang metode itu. Hasil yang diharapkan tidak sesuai dengan tujuan awalnya.

Oleh karena itu, pengajar harus benar-benar mantap dalam menerapkannya, mempersiapkan sebelum proses pembelajaran itu adalah suatu keharusan agar penerapan metode tercapai dengan baik, serta hasilnyapun bisa terasa kepada santrinya.

\section{Buku Al-fatih}

Pengertian buku Al-fatih adalah nama lain dari sebuah metode baca cepat kitab kuning. secara umum masih samar didengar oleh khalayak atau orang lain buku tersebut dinyatakan oleh pihak pengajar bahwa buku tersebut berhasil meningkatkan minat dan kemahiran dalam membaca para santri.

Namun dalam sejarah penerapan buku Al-fatih sudah pernah dikembangkan sejak Tiga tahun lalu di kota Madura oleh KH A Mufthi. ${ }^{4}$ Namun untuk di pondok

${ }^{4}$ Mufthi, http:// Jatim. Santrinews.Com/ Metode Al Fatih Kaidah-Kaidah Baca Kitab kuning (11 Desember 2020) 
pesantren Madinatul Ilmi DDI Siapo buku Al-fatih ini masih baru-baru di terapakan dan yang menerapkan langsung buku ini yaitu Ustadz Ridwan Alumni Pondok pesantren Rejosari Magelang yang belajar langsung penerapan buku Al-fatih ini, dan sekarang beliau menerapkan di pondok pesantren Madinatul Ilmi DDI Siapo Tolitoli Sulawesi Tengah.

2. Model-model pembelajaran buku Al fatih

dalam penerapan buku Al-fatih ini menyajikan beberapa model pembelajaran, sebagai berikut:

a. Pembelajaran langsung

Pembelajaran langsung pada umumnya dirancang secara khusus untuk mengembangkan aktivitas belajar santri yang berkaitan dengan aspek pengetahuan procedural (pengetahuan tentang bagaimana melakasanakan sesuatu) dan penegtahuan deklaratif (penegtahuan tentang sesuatu yang dapat brupa fakta, konsep, prinsip, atau generalisasi) yang terstruktur dengan baik dan dapat dipelajari selangkah demi selangkah. ${ }^{5}$

b. Pembelajaran model latihan (Drill)

Drill atau latihan secara enofatif merupakan tindakan untuk meningkatkan

\footnotetext{
${ }^{5}$ Abdul Majid,Strategi Pembelajaran (bandung: PT. Remaja Rosdakarya, 2013), 72

${ }^{6}$ Ibid,.214

${ }^{7}$ Rosalin, E.,Gagasan merancang pembelajaran kontekstual (Bandung: Karsa Mandiri Persada, 2008), 112
}

keterampilan dan kemahiran serta dapat mengembangkan sikap dan kebiasaan, karena latihan atau berlatih merupakan proses belajar dan membiasakan diri agar mampu melakuakan sesuatu. ${ }^{6}$

\section{c. Pemebelajaran kontekstual}

Pembelajaran yang diawali dengan sajian atau Tanya jawab lisan yang ramah dan terbuka terkait dengan kehidupan sehari-hari para santri, sehingga mereka mengetahui manfaat dari materi yang disajikan, motivasi belajar pada diri muncul, dunia pemikiran para santri jadi konkrit, suasana menjadi kondusif dan menyenangkan. Prinsipnya peserta didik aktif melakukan dan tidak hanya mengalami mencatat yang monoton. ${ }^{7}$

3. Perbedaan buku Al- fatih dan Metode Membaca Kitab Kuning Lainnya

Buku Al-fatih merupakan adaptasi dari pembelajaran kitab kuning di pesantren-pesantren salaf. yang bahkan jauh hari, Syaikhona KH Kholil bangkalan juga sudah menerapkan pembelajaran buku Al-fatih Hal ini dikatakan oleh KH A Mufthi sendiri. ${ }^{8}$ "hanya ada sedikit tambahan dan modifikasi lugasnya."9

${ }^{8}$ Mufthi, http://Jatim.Santrinews.com/metode Al-fatih-kaidah baca kitab kuning(11 Desember 2020)

${ }^{9}$ Ibid., Mufti., (11 Desember 2020) 
Penerapan buku Al-fatih tidak jauh berbeda dengan metode baca kitab lain hanya dari isi buku pembelajarannya yang berbeda. Adapun isi buku pembelajaran dalam penerapan buku Al-fatih, ialah:

a. Menggunakan 3 jilid buku yang sudah disediakan oleh Ustad /pengajar adapun buku tersebut yaitu:

\section{Tabel nahwu Al-fatih}

2. Al-mun̄̄r buku praktek baca Alfatih

\section{Tașrif dan I'lāl Al-fatih}

b. Pertama menggunakan buku tabel $n a h w u,{ }^{10}$ dalam buku tabel nahwu ini di dalamnya terdapat beberapa bab pembahasan dan terdiri dari Level 1-6. Level-level yang di bahas dalam buku table Nahwu Al-fatih dari level satu sampai enam yaitu:

1. المستوى الآول : pembagian kata, tanda isim, macam-macam isim, huruf jar, fiil, i'rob, tanda i'rob rafa, tanda i'rab naşab, tanda i'rab jar, tanda i'rab jazem, isim majrur, asmaul khomsah, isim marfu', fail, nāibul fāil.

2. Mubtada dan khabar, isim kāna dan saudaranya, khabar inna, tābi', naat, athaf, taukid, badal.
3. الثنتوى الثنالث : Hukum fiil, fiil mādi, fiil amar, fiil muḍāri, fiil muḍāri mansūb, fiil muḍāri majzum, isim mansūb, maf'ul bih, maf'ul mutlāq, ẓaraf, hāl, tamyiz, mustasna.

4. المستوى الر ابع : Munada, isim la, maf'ul min ajlih, maful ma'ah, isim ghairu munşarif, z̧onna, isim mabni, isim damir, isim isyārah, isim mausūl, isim syarat, isim istifham, isim fiil,.

5. : : Af'alul muqarrabah, af'alul raja, af'alul syuru', huruf yang beramal seperti laisa, ighra, tahdzir dan ikhtisos, af'alul māḍi wadzzam, isim tafdhil dan fiil ta'jub, adad, bilangan urutan, kata dengan kedudukan tertentu.

6. المستوى السادس : makna huruf.

c. Kedua menggunakan buku tașrif dan I'lāl, ${ }^{11}$ Dalam buku tașrif dan I'lāl ini santri mempelajari bagaimana cara cepat mentașrif dan mengi'lāl dengan mudah dan cepat agar memudahkan mereka dalam membaca kitab gundul/kuning (tidak berharakat). Tidak hanya itu dalam buku Taṣrif dan I'lāl juga mempunyai pembahasan yang 
terdiri dari 1-6 level juga sama seperti buku Nahwu Al-fatih yaitu:

1. pengantar taşrif, taşrif lughawi bagian 1.

2. المستوى الثانى: fiil thulasi şahih dan rubai'.

3. fiil khumasi dan thudasi.

4. المستوى الرابع : fiil thulasi.

5. tasrif lughawi bagian dua, faidah perubahan wazan.

6. المستوى السادس : i'lāl dan idgham.

Program pembelajarannya, para santri mampu menguasai tașrif selama 3-6 bulan untuk cepat bisa membaca kitab gundul dan kitabkitab bahasa Arab.

d. Terakhir menggunakan buku AlMunīr, ${ }^{12}$ Buku ini adalah buku praktek membaca dan di dalam pembahasannya merupakan beberapa kumpulan bacaan yang diambil dari beberapa kitab yaitu:

1. Al-Arabiyah baina yadaik jilid 2

2. Fathul mu'in

3. Hayātu al șhabat

4. Dan tafșir as-sa'di

Di dalam buku ini juga dilengkapi dengan latihan

\footnotetext{
${ }^{12}$ Samsul Maarif, Al-munir Pesantren Annur pakis,cetakan Juni 2019.
}

penerjemahan dari Bahasa Indonesi ke Bahasa Arab.

\section{Peningkatan Kemahiran Membaca}

\section{kitab kuning}

1. peningkatan kemahiran membaca Untuk meningkatkan keterampilan atau kemahiran membaca, Tarigan menyarankan agar pengajar melakukan beberapa hal, yaitu ${ }^{13}$ :

a. Menolong para pembelajar memperkaya kosakata dengan memperkenalkan aspek-aspek penting bahasa seperti sinonim, antonim, frasa, klausa, dan sebagainya.

b. Membantu para pembelajar untuk memahami makna dan struktur yang diajarkan dengan cara memperbanyak contoh dan latihan.

c. Jika diperlukan, pada tingkat dasar pengajar bias memperkenalkan unsur-unsur gaya bahasa, peristilahan, kata-kata pepatah, dan sebagainya.

d. Memastikan pemahaman pembelajar tentang struktur kalimat yang diajarkan dengan memberi variasi kalimat yang sama, seperti dari kalimat berita menjadi pertanyaan, larangan, sindiran, dan sebagainya.

${ }^{13}$ Acep Herman, Metodologi Pembelajaran Bahasa Arab (Bandung:Remaja Rosdakarya,2011),hlm 41 
e. Melatih pemeblajar untuk membaca cepat, misalanya memberi durasi waktu tertentu dalam membaca bebrapa kalimat atau paragraf.

Kemahiran dalam kamus besar bahasa indonesia KBBI berasal dari kata "mahir" yang mendapat awalan ke- dan akhiran-an, yang berarti keterampilann kecakapan, untuk melakukan sesuatu. Ada empat keterampilan dan kemahiran dalam Bahasa Arab yaitu:

1) مهارة الإستماع (kemahiran menyimak) Kemahiran atau keterampilan menyimak (mahārat al-istimā') adalah kemampuan seseorang dalam mencerna dan memahami kata atau kalimat yang diujarkan oleh mitra bicara atau media tertentu. ${ }^{14}$

2) مهارة الكلام (Kemahiran berbicara) Menurut Acep Hermawan, kemahiran atau keterampilan berbicara (mahārah al-kalām), adalah kemampuan mengungkapkan bunyi-bunyi artikulasi atau kata-kata untuk mengekspresikan pikiran berupa ide, pendapat, keinginan atau perasaan kepada mitra bicara. ${ }^{15}$

3) مهارة القرأة (Kemahiran membaca)

\footnotetext{
${ }^{14}$ Ibid, 130

${ }^{15}$ Ibid, hlm135

${ }^{16}$ Acap Hermawan, Pembelajaran Keterampilan Berbahasa Arab dengan Pendekatan komunikatif Interaktif (Bandung: Alfabeta, 2018), $\mathrm{hlm} 39$.
}

\begin{abstract}
Membaca adalah kemampuan mengenali dan memahami isi sesuatu yang tertulis (lambanglambang tertulis) dengan melafalkan atau mencernanya di dalam hati. Kemahiran membaca juga merupakan suatu keterampilan yang sangat unik dan penting bagi pengembangan pengetahuan, juga sebagai alat komunikasi bagi kehidupan manusia. ${ }^{16}$
\end{abstract}

4) مهارة الكتابة (Kemahiran menulis)

Kemahiran atau keterampilan menulis (Mahārah al-kitābah), adalah kemampuan dalam mendeskripsikan atau mengungkapkan isi pikiran, mulai dari aspek yang paling sederhana, seperti menulis kata-kata, sampai kepada aspek yang kompleks yaitu mengarang. ${ }^{17}$

Membaca merupakan suatu keterampilan yang sangat unik dan penting bagi pengembangan pengetahuan, juga sebagai alat komunikasi bagi kehidupan manusia. membaca juga merupakan salah satu dari empat keterampilan berbahasa yang diajarkan, karena itu berkonsekuensi untuk diteskan kepada pembelajar bahasa. ${ }^{18}$

\footnotetext{
${ }^{17}$ Ibid, hlm. 151.

18 Acep Hermawan,Pemebelajaran Keterampilan Berbahasa Arab (Bandung: Alfabeta,cv 2018) 39,40.
} 
Membaca juga merupakan kegiatan untuk mendapatkan makna dari yang tertulis dalam teks. Untuk keperluan tersebut, selain harus menguasai bahasa yang dipergunakan, seorang pembaca perlu juga mengaktifkan berbagai proses mental dalam sistem kognisinya. ${ }^{19}$

Pada hakikatnya, membaca adalah proses komunikasi antara pembaca dengan penulis melalui teks yang ditulisnya. Oleh karena itu, pengajaran membaca perlu memperoleh perhatian serius, dan wacana membaca tidak boleh hanya dipandang sebagai batu loncatan bagi aktivitas bicara dan menulis semata. Adapaun Kemahiran membaca mencakup dua hal, yaitu mengenali simbol- simbol yang tertulis dan memahami isinya. ${ }^{20}$

Dari empat keterampilan atau kemahiran di atas membaca merupakan salah satu dari keterampilan berbahasa yang di ajarkan, karena itu berkonsekuensi untuk di teskan kepada pembelajar Bahasa Arab. Bersama dengan kemampuan menyimak kemampuan membaca juga tergolong kemampuan aktif reseptif, namun berbeda media penyampainnya.Kemampuan menyimak dipergunakan untuk mengukur kemampuan memahami bahasa lisan

\footnotetext{
${ }^{19}$ Iskandarwassid dan Sunendar, Strategi Pemebelajaran Bahasa Arab ( Bandung: Remaja Rosda Karya, 2008), 246
}

sedangkan kemampuan membaca untuk bahasa tulisan. ${ }^{21}$

\section{Kitab kuning}

Salah satu tradisi agung di Indonesia adalah tradisi pengajaran agama Islam seperti yang muncul dipesantren jawa dan lembaga-lembaga serupa diluar jawa serta semenanjung Malaya. Alasan pokok munculnya pesantren ini adalah untuk mentransmisikan Islam tradisional sebagaimana yang terdapat dalam kitabkitab klasik yang ditulis berabad-abad yang lalu yang dikenal dengan kitab kuning. Jumlah teks klasik yang diterima di pesantren sebagai ortodoks ( al-kutub almu'tabarah) pada prinsipnya terbatas. ${ }^{22}$ Kitab-kitab klasik berbahasa Arab jelas sudah dikenal dan dipelajari pada abad ke16, beberapa kitab pada zaman itu sudah diterjemahkan kedalam bahasa jawa dan melayu, sementara beberapa orang Indonesia telah menulis kitab-kitab dalam bahasa tersebut dengan gaya dan isi yang serupa dengan kitab ortodoks.

Istilah kitab kuning itu muncul di lingkungan pondok pesantren yang ditujukan kepada kitab-kitab ajaran Islam yang ditulis pada Abad pertengahan dengan berbahasa Arab tanpa harakat dan arti yang biasanya kertasnya berwarna kuning, akan

\footnotetext{
${ }^{20}$ Ulin Nuha, M.Pd.I.,Ragam Metodologi dan Media Pembelajaran Bahasa Arab (Banguntapan Yogyakarta: Diva Press 2016), 100

${ }^{21} \mathrm{lbid}, \mathrm{hlm} 40$.

22 Ibid, hlm13-14
} 
Al Bariq : Jurnal Pendidikan Bahasa Arab, 2, (2), 2021,

tetapi kitab-kitab sekarang ada yang dinamakan kitab kuning dan kitab putih, yang dinamakan kitab kuning adalah kitab yang digunakan oleh pondok-pondok salaf yang dikaji oleh para santri yang biasanya dipimpin langsung oleh seorang Kiai atau Ustadz. Sedangkan yang dinamakan dengan kitab putih adalah kitab-kitab yang sudah populaer dikalanagn masyarakat, dan biasanya lebih digunakan di perguruan tinggi seperti tentang hukum-hukum dll. Untuk kitab kuning sampai sekarang masih digunakan di pondok pesantren hingga kini. Salah satunya di pondok pesantren DDI Siapo yang masih sampai sekarang menggunakan kitab kuning, dalam pondok pesantren tersebut mempelajari beberapa kitab kuning diantaranya yaitu: Fathu al qarīb, Ta'lim al muta'llim, Aqīdatul Awām, Riyạ̄̂ al șlihīn dan tafsīr jalālain.

Kitab kuning adalah kitab-kitab klasik yang ditulis berbahasa Arab dan edisi-edisinya kebanyakan berwarna kuning. ${ }^{23}$ Kitab kuning disebut dengan istilah kitab kuning karena pada umumnya kitab ini dicetak diatas kertas berwarna kuning. berkualitas rendah dan beberapa macamnya hanya susunan cetakan tidak dijilid. kitab kuning juga biasa diistilahkan sebagai Al-kutub Al-qādimat (kitab-kitab

\footnotetext{
${ }^{23}$ Ahamadi Rulam, Pengantar Pendidikan: Asas dan Filsafat Pendidikan(Yogyakarta: Ar Ruzz Media, 2017), 152.

${ }^{24}$ Muhammad Thoriqussud 2012,

Pengembangan Kajian Kitab Kuning di
}

kelasik/kuno). istilah yang di sebut guna menyebut kitab kuning adalah kitab gundul sebab penulisan Arab dalam kitab itu tanpa syakal, tanpa tanda baca dan pemberhentian. ${ }^{24}$

Metode pembelajaran di pondok pesantren ada yang bersifat tradisional yaitu metode yang di selenggarakan menurut kebiasaan yang telah lama dilaksanakan di pondok pesantren biasa juga disebut dengan metode (original). Berikut ada beberapa metode tradisional yang dipakai dalam pembelajaran kitab kuning di pondok-pondok pesantren, antara lain sebagai berikut:

\section{a. Metode sorogan}

Dalam metode sorogan ini dimana santri diminta satu persatu maju membawa kitab masing-masing, dimana kiai memebacakan beberapa baris dari kitab dan membacakan maknanya, kemudian santri mengulangi bacaan kiainya atau yang telah kiai bacakan. ${ }^{25}$ Sistem sorogan bias dibilang sangat efektif sebagai taraf pertama seorang santri, sorogan merupakan kegiatan pembelajaran bagi santri yang lebih menitik beratkan pada pengembangan kemampuan perorangan (Individual), di bawah bimbingan seorang kiai/ustadz.

b. Metode hafalan

Pondok Pesantren, Jurnal Ilmu Tarbiyah" At-Tajdid" Vol 1,No. 2, Juli 2012

${ }^{25}$ Van Hoeve, Ensiklopedia Islam, ( Jakarta: PT. Ichtiar Baru, 2000) 336 
Metode ini merupakan metode unggulan dan sekaligus metode ciri khas yang melekat pada pondok pesantren sejak zaman dulu hingga sekarang. Metode hafalan ialah kegiatan belajar santri dengan cara menghafal suatu teks tertentu dibawah bimbingan kiai/ustadz, biasanya para santri diberi tugas untuk menghafalakan bacaan atau mufradat pada jangka waktu tertentu.

c. Metode wetonan/Bandongan

Metode ini diterapkan secara klasikal, biasanya seorang kiai/pengajar membacakan sebuah kitab kuning dengan kata demi kata sekaligus dengan terjemahannya dan biasa menggunakan bahasa jawanya dan biasanya disertai dengan penjelasannya atau keterangannya, sedangkan para santri menyimak bacaan dan sambil memeberikan catatan-catatan pada kitab-kitab mereka masing-masing. jadi, tidak semua terjemahan kiai/pengajar harus ditulis oleh santri namun hanya dari kata-kata yang belum diketahuinya yang diberi catatan.

\section{d. Metode halaqah}

Metode halāqah adalah sekelompok santri tertentu membahas permasalahan, baik yang diberikan kiai/pengajar ataupun masalah yang benar-benar terjadi di masyarakat. Diskusi ini dipimpin oleh seorang santri dengan pengamatan dari

\footnotetext{
${ }^{26}$ Abdurrahman Saleh, Pedoman Pembinaan Pondok Pesantren, (Jakarta: Departemen Aagama RI, 1982), 79
}

kiai/pengajar yang mengoreksi dari hasil diskusi. $^{26}$

$$
\text { Dari beberapa metode }
$$
pemebelajaran kitab kuning di atas pada kegiatan pondok pesantren masih banyak yang menggunakan metode-metode tersebut apalagi dalam pondok-pondok pesantren salaf. Seiring perkembangan zaman banyak sudah muncul metodemetode baru namun tujuan pengajarannya masih sama, dalam pembelajaran kitab kuning kita lebih ditekankan dalam penguasaan ilmu nahwu șaraf agar tidak salah dalam memaknai atau menterjemahkan.

Untuk itu sudah banyak di pondokpondok pesantren menggunakan metodemetode cepat baca kitab salah satunya di pondok pesantren Madinatul Ilmi DDI Siapo Toli-Toli dimana di pondok tersebut menerapkan metode Al-fatih untuk meningkatkan kemahiran memaca kitab kuning.

\section{METODE}

Penelitian ini, penulis mengunakan pendekatan penelitian kualitatif deskriptif, yaitu mendeskripsikan Penerapan buku Alfatih dalam meningkatkan kemahiran membaca kitab kuning di pondok pesantren DDI Siapo Toli-Toli.

\section{HASIL DAN DISKUSI}


Al Bariq : Jurnal Pendidikan Bahasa Arab, 2, (2), 2021,

\section{Penerapan buku Al-fatih di pondok pesantren Madinatul Ilmi DDI Siapo}

Pencetus pertama buku Al-fatih adalah pondok pesantren An-Nur Rejosari pakis magelang, kemudian Pondok Pesantren Madinatul Ilmi mengikuti jejak pembelajaran penerapan buku Al-fatih yang diterapkan di pondok pesantren An-Nur Rejosari Pakis Magelang, seperti yang di jelaskan oleh ustad Ridwan sebagai alumni pondok pesantren magelang sendiri dan yang mengajar langsung penerapan buku Al-fatih di pondok pesantren Madinatul Ilmi. ${ }^{27}$ Sejarah diterapkannya buku Alfatih:

Awal sejarah adanya penerapan buku Al-fatih ini di terapkan di pondok pesantren Madinatul Ilmi dikarenakan sebelumnya pengajaran yang masih menggunakan metode klasik, dengan hafalan jurumiyah, imriti dan alfiyah, yang belum ada peningkatan dalam pembelajaran membaca kitab kuning. Namun, setelah terterapkannya buku baru ini dari salah satu santri mengatakan bahwasannya "dengan adanya terbitnya buku baru ini yaitu Alfatih, kesan belajar nahwu yang sebelumnya membuat bingung dan sangat menyulitkan dan setelah diterapkan buku Al-fatih ini

\footnotetext{
${ }^{27}$ Ridwan, Pengajar Buku Al-Fatih Pondok Pesantren Madinatul Ilmi DDI Siapo, wawancara, 18 Maret 2021.

${ }^{28}$ Tiara Wulandari, Santri Pondok Pesantren Madinatul Ilmi DDI Siapo wawancara, Gazebo Depan Pondok Pesantren,23 Maret 2021.
}

pembelajaran menjadi super mudah dan memuaskan bagi santri Madinatul Ilmi”, ${ }^{28}$

Penerapan buku Al-fatih di pondok pesatren Madinatul Ilmi DDI Siapo yaitu sebagai berikut:

\section{1. perencanaan}

perencanaan berasal dari kata rencana yang mendapat awalan pe dan akhiran an, berarti suatu proyeksi aktivitas yang dilakukan. Dalam Bahasa Arab perencanaan disebut dengan kata. تخطيط29 Misalnya تخطبط المناهج (Perencanaan Kurikulum), التخطيط التربية (Perencanaan Pendidikan), عملية التخطيط (Proses Perencanaan). Dengan demikian perencanaan adalah sebuah konseptualisasi dari sekian banyak aktivitas, dalam bentuk program-program, tersusun secara sistematis, logis, jelas makna dan tujuannya.

Dalam sistem perencanaan pada penerapan buku Al-fatih di Pondok pesantren Madinatul Ilmi rencana pembelajaran pada penerapan buku Al-fatih ini dibuat berdasarkan dimana seorang ustadz pada penerapan buku Al-fatih ingin para santri yang pertama kali mengikuti penerapan buku ini dapat meningkatkan kemahirannya dalam membaca kitab

${ }^{29}$ Muhammad Ali al- Khauly, Qamus AtTarbiyah, Inggris-Arab.(Beirut: Dar Al- Ilm Li AlMalayin, 1981), hlm 355 
kuning, yang mana pada strategi atau teknik penyampainnya materi ini lebih cenderung pada penguasaan materi latihan dan praktek maka rencana pembelajaran memuat hal-hal berikut: 1. materi yang akan diajarkan dalam penerapan buku Al-fatih itu menggunakan 3 jilid buku, yang membahas tentang Nahwu, Tasrif, I'lāl dan Al-munìr. Dari ketiga buku itu sudah tersusun dari beberapa materi dari setiap levelnya, untuk buku jilid yang pertama yang akan di pelajari yaitu ilmu nahwu, materi dalam buku ilmu Nahwu terdiri dari 6 level dan masing-masing level terdiri dari beberapa pembahasan. sedangkan dalam buku Ilmu Taṣrif dan I'lāl nya sama terdiri dari 6 level juga dan terbagi dari beberapa materi pembahasan, jadi dalam setiap pengajarannya dari setiap level ada latihan dan peraktek agar santri tidak mudah lupa dan selalu muraja'ah pelajaran yang sudah di pelajari dari hari sebelumnya. 2. dalam proses penerapan pengajaran dan pembelajaran pada buku ini tidak semua santri bisa ikut jadi, dalam penerapan buku ini diperuntukan hanya beberapa santri saja yang akan diseleksi pastinya yang mempunyai dasar Bahasa Arab dan bagus bacaan Al-Qur'annya. Jadi tidak semua santri bisa mengikuti penerapan buku Alfatih baru ini hanya beberapa santri saja yang mengikuti dalam pembelajaran buku Al-fatih ini, yaitu masing-masing 6 dari santri putra dan 6 dari santri putri.
Dari setiap santri putra dan santri putri masing-masing yang sudah mempunyai dasar pembelajaran bahasa Arabnya terutama yang bisa baca AlQur'an karena pada penerapan buku ini dibuat semacam kursusan yang mana santri diminta untuk fokus dalam pembelajaran materi dan latihan-latihan yang diberikan. Mereka semua yang mengikuti penerapan buku Al-fatih sudah melaksanakan tes awal untuk masuk dalam pembelajaran penerapan metode Al-fatih.

Jadi, dari perencanaan dalam penerapan buku Al-fatih tersebuat para santri diminta agar dapat menyelesaikan dalam waktu 6 bulan lamanya, dengan waktu yang sudah ditentukan dan sudah disusun sedemikian maksimal, agar dalam pemebelajaran penerapan buku ini bisa berjalan dengan lancar sampai para santri mampu dan mahir membaca kitab kuning dalam waktu singkat 6 bulan.

\section{2. pelaksanaan}

Pelaksanaan pemebelajaran pada santri Madinatul Ilmi DDI Siapo akan terlaksana setelah semua santri siap untuk mengikuti kegiatan pembelajaran dan setelah semua kebutuhan belajar mengajar sudah terpenuhi atau sudah siap semua. Pada tahap pelaksanaan ini dimana seorang ustadz atau pengajar lebih menekankan pada kemampuan mengajar untuk memahamkan santri-santrinya terhadap penerapan buku Al-fatih. 
Dalam penerapan buku Al-fatih ini Ustadz pengajar Al-fatih menggunakan metode ceramah dan metode hafalan, karena dalam materi pembelajaran Al-fatih ini sama halnya dengan pembelajaran kitabkitab kuning lainnya yaitu pembelajaran Nahwu dan șaraf Itaṣrīf. Untuk lebih memahamkan para santri mengenai materi apa yang telah mereka pelajari harus terus di ulang-ulang oleh Ustadz pengajar buku Al-fatih agar santri tidak mudah melupakan apa yang telah mereka pelajari.

Pada tahap ini terdapat beberapa proses yang ditempuh untuk menyelesaikan pembelajaran Al-fatih pelaksanaan pemebelajaran Al-fatih dilakukan pada waktu yang telah ditentukan mulai pada pukul 09.00-12.00 WITA. Seperti yang dikatakan oleh Ustadz Ridwan selaku pengajar Al-fatih di Pondok pesantren Madinatul Ilmi DDI Siapo dan juga sebagai pimpinan ketua Yayasan Nur Salim ToliToli. " Pada pembelajaran penerapan buku Al-fatih ini dalam seminggu 4 kali pertemuan dan santri yang mengikuti hanya berjumlah 12 orang saja karena ini masih tahap awal pada penerapan buku Al-fatih"30

Kegiatan belajar mengajar buku Alfatih dimulai pada hari senin diruang belajar sekolah Pondok Pesantren Madinatul Ilmi DDI Siapo hingga sampai pada hari jum'at dan untuk hari sabtu dan ahad para santri

\footnotetext{
${ }^{30}$ Ridwan , Pimpinan Pondok Pesantren Madinatul IImi DDI Siapo dan Pengajar Metode Al-
}

yang telah belajar Al-fatih maka wajib untuk mengajarkan kembali kepada temanteman yang tidak mengikuti penerapan buku Al-fatih.

Buku Al-fatih memiliki 3 jilid buku, namun dalam penerapan buku Al-fatih tidak langsung dalam satu waktu, akan tetapi melalui tahap-tahap yang sudah ditentukan oleh pengajar Al-fatih langsung. Ustadz Ridwan sebagai pengajar langsung penerapan buku Al-fatih juga menyampaikan secara singkat bagaimana proses pembelajaran Al-fatih di Pondok pesantren Madinatul Ilmi DDI Siapo, mengatakan bahwa:

"Penerapan metode sangat diperlukan sekali karena metode ini sangat berpengaruh kepada sistematisnya suatu pendidikan pengajaran jika menggunakan suatu metode perkara yang mungkin ditempuh dengan jalur yang agak lama bisa menjadi jalur yang lebih singkat bahkan akan memberikan kemudahan para santri baik dengan metode apapun apalagi yang kami terapkan yaitu buku Al-fatih yang bisa memberikan kesan memberi kemudahan dan peningkatan kepada para santri untuk mempelajari ilmu Nahwu dan Taşrīf, I'lāl agar mudah cepat baca kitab kuning. Dalam 
penerapan buku ini dibutuhkan waktu maksimal 6 bulan saja. penerapan buku ini menggunakan 3 Jilid buku jilid pertama mempelajarai tentang kaidah-kaidah Ilmu Nahwu dan yang jilid ke dua mempelajari tentang şaraf / taşrīf (asal usul kata) atau akar kata atau membentuk berbagai picahan kata dari suatu kata dan I'lāl adalah membuang, mengganti, mematikan atau memindah harakat huruf ilat (ya, alif dan waw). dimana jilid yang ke tiga yaitubuku Al-munīr adapun didalam isi buku atau jilid tersebut yaitu memuat isi yang diambil dari beberapa kitab yang untuk dijadikan bahan latihan-latihandan praktek langsung membaca kitab yang tanpa harakat biasa dikenal dengan kitab kuning.dan pastinya dalam setiap pembelajran banyak hafalan-hafalan mufradat (kosa kata) yang para santri hafalakan agar untuk lebih mempermudah dalam membaca kitab kuning. ${ }^{31}$

Proses pada penerapan buku Alfatih ini di terapkan selama 6 bulan maksimal, dengan sistem 46 jam (5 kali tatap muka/ minggu), dimana penerapan buku Al -fatih ini dalam setiap level ada latihan-latihannya setelah itu dalam setiap level ada beberapa bab pembahasan dan ujian kenaikan level. jadi pada penerapan buku ini lebih banyak digunakan dalam sistem latihan dan praktek agar santri terbiasa dan selalu mengulang- ngulang dan mengingat apa yang telah mereka pelajari.

\section{Evaluasi}

Adapun untuk melihat hasil dari evaluasi pada penerapan buku Al-fatih ini dengan memberikan nilai dalam setiap latihan, praktek pada setiap Bab dan kenaikan levelnya. Sedangkan mereka tidak akan dinaikkan ke level selanjutnya apabila mereka tidak mencapai target yang ditentukan. adapun nilai target yang harus mereka capai sekitar 8-9\%, apabila mereka tidak mencapai nilai yang sudah ditentukan maka mereka harus mengulangi ujian kembali agar mencapai target yang sudah ditentukan.

langkah-langkah penerapan buku Alfatih dalam meningkatkan kemahiran membaca kitab kuning dipondok pesantren Madinatul Ilmi DDI Siapo Toli-Toli

Adapun dari hasil yang peneliti dapatkan melalui wawancara, observasi dan dokumentasi yaitu, dari penjelasan 
penerapan buku Al-fatih di atas dari beberapa penjelasan tetang penerapan buku Al-fatih mulai dari perencanaan, proses pelaksanaan dan sampai ke evaluasi dapat dikatakan bahwasannya di lihatnya hasil peningkatan kemahiran membaca kitab kuning dalam penerapan bukuAl-fatih dapat dilihat dari beberapa langkah-langkah penerpan buku Al-fatih dan indikator pencapaian yaitu :

Kegiatan belajar mengajar yang dilakukan di Pondok Pesantren Madinatul Ilmi DDI Siapo dengan menggunakan buku Al-Fatih meliputi beberapa langkah atau proses pengajaran buku Al-fatih sebagai berikut:

1. Mengawali dengan do'a sepenuh hati agar ilmu yang dipelajari berkah dan bermanfaat.

2. Memberikan motifasi 2-5 menit, diantaranya:

- حياة الفتى والله با لعلم والتقى ا ذا لم يكو ن ا لا لا اعتبا ر لذاته

- من صبر ظفر

• صا حب الممة لا يحجزه شيئ

- من جد وجد

- من سار و صل

3. Santri diberikan materi dan setelah diberikan materi beberapa menit kemudian diberikan latihan-latihan agar santri terbiasa dan mudah mengingat pelajaran-pelajaran yang sudah diberikan.
4. Para santri juga di tekankan untuk mengahafal setiap mufradat yang suadah di pelajari dalam setiap latihan

5. Santri biasanya setelah diberikan materi lalu mengerjakan soal latihan sendiri atau berkelompok

6. Setiap santri yang sudah menyelesaikan tugas latihanya Ustadz langsung mengoreksi secara lisan maupun tulisan

7. Penutup, sebelum Ustdz menutup pembelajaran, Ustad memberi kesempatan kepada santri untuk bertanya dan setelah itu Ustad mengakhiri pembelajaran dengan membaca do'a.

Dari beberapa langkah-langkah penerapan di atas, peningkatan kemahiran membaca juga dapat dilihat dari beberapa pencapaian indikator sebagai berikut:

1. Meningkatnya Penguasaan terhadap materi. Penguasaan materi yang dimaksud disini adalah mampu memahami isi dari pembelajaran pada setiap materi pembahasan yang dijelaskan oleh Ustadz pengajar Alfatih karena dari setiap level nya ada beberapa materi pembahasan dari setiap babnya. setiap kali tatap muka santri diberikan latihanlatihan dan praktek langsung dan selalu mengulang-ngulang apa yang telah mereka pahami dan pelajari 
dan dari apa yang santri pelajari dari situlah dilihat apakah mereka menguasai dan faham dengan materi yang diberikan atau tidak.

2. Mampu untuk mempraktekkan. Pada Penerapan buku Al-fatih ini indikator peningkatan dalam kemampuan peraktek santri lebih dominan dibanding yang lain karena dari peraktek atau latihan-latihan santri dapat dilihat keberhasilan yang telah mereka capai, mulai dari segi membaca, mengi'rab bahkan sampai materi yang sudah mereka fahami karena nilai pencapaiannya dalam perkatek santri sampai $90 \%$.

3. Meningkatnya minat Membaca. Indikator pencapain yang ketiga yaitu mampu membaca kitab langsung di kitab-kitab yang ful tanpa harakat. Karena dengan penerapan buku Al-fatih ini ada buku Almunīr yang di khususkan dalam pelatihan-pelatihan membaca langsung yang mana dalam buku ini santri diharapkan mampu membaca kitab kuning dengan lancar dan tidak hanya itu kualitas membaca kitab kuning pada santri dikatakan sudah meningkat apabila santri tepat dalam membacanya bukan hanya sekedar lancar, tetapi juga tepat dalam membacanya setiap akhir kalimat atau harakat akhirnya, apalagi dalam penerapan buku Alfatih ini dalam setiap pembelajaran per Levelnya untuk pembahasan ilmu Nahwu sudah banyak latihanlatihan yang diberikan kepada santri setiap pembelajarannya.

\section{KESIMPULAN}

Dalam penerapan buku ini menggunakan 3 jilid buku yaitu: nahwu, șaraf dan buku praktek membaca dan untuk setiap buku nahwu dan șaraf mempunyai 6 level dari beberapa Bab pembahasan.

Langkah-langkah penerapan buku Al-fatih dalam meningkatkan kemahiran membaca kitab kuning yaitu menggunakan tiga jilid buku yang mana langkah-langkah pertama menggunakan buku Nahwu Alfatih, yang ke dua buku Tafsir I'lal dan yang ke tiga yaitu buku praktek baca kitab nama buku tersebut Al-munir. Adapaun untuk dapat melihat peningkatan dari membaca kitab dapat dilihat dari tiga indikator pencapaian yaitu: yang pertama meningkatnya penguasaan terhadap materi dilihat dari bagaimana mereka memhami semua materi yang sudah diajarkan dan mampu menjawab pertanyaan-pertanyaan seputar materi dan Latihan latihan dari setiap materi. Yang kedua yaitu mampu untuk mempraktekan dalam hal ini santri mampu langsung Mempraktekkan pada buku praktek Almunīr yang mana dalam buku tersebut sudah terdiri dari kumpulan 
Al Bariq : Jurnal Pendidikan Bahasa Arab, 2, (2), 2021,

beberapa kitab, jadi bisa dilihat peningkatan santri dari kemampuan praktek membaca, mengi'rab dan menghafal materi yang sudah diajarkan yang ketiga yaitu meningkatnya dalam kemampuan membaca kitab dalam hal ini santri dikatakan ada peningkatan apabila dapat membaca kitab dengan tepat tidak hanya sekedar membaca tapi mampu memahami juga apa yang mereka baca.

\section{DAFTAR PUSTAKA}

Abdul Majid,Strategi Pembelajaran (bandung: PT. Remaja Rosdakarya, 2013)

Abdurrahman Saleh, Pedoman Pembinaan Pondok Pesantren, ( Jakarta: Departemen Aagama RI, 1982)

Acap Hermawan, Pembelajaran

Keterampilan Berbahasa Arab dengan Pendekatan komunikatif

Interaktif (Bandung: Alfabeta, 2018)

Acep Herman, Metodologi Pembelajaran

Bahasa Arab (Bandung:Remaja

Rosdakarya,2011)

Azhar Arsyad,Suatu Psikodinamik Terhadap Metodelogi Bahasa Asing Inofatif(Jakarta:Al-Quswa, 1989)

Departemen Pendidikan dan KebudayaanR.I, Kamus Besar
Bahasa Indonesia. cet.III, (Jakarta:

Balai Pustaka,1994)

Iskandarwassid dan Sunendar, Strategi Pemebelajaran Bahasa Arab ( Bandung:

Mufthi, http:// Jatim. Santrinews.Com/ Metode Al Fatih Kaidah-Kaidah Baca Kitab kuning (11 Desember 2020)

Mufthi,

http://Jatim.Santrinews.com/metode Al-fatih-kaidah baca kitab kuning(11 Desember 2020)

Muhammad Ali al- Khauly, Qamus AtTarbiyah, Inggris-Arab.(Beirut: Dar Al- Ilm Li Al-Malayin, 1981)

Muhammad Thoriqussud 2012, Pengembangan Kajian Kitab Kuning di Pondok Pesantren, Jurnal Ilmu Tarbiyah" At-Tajdid" Vol 1,No. 2, Juli 2012

Ridwan, Pimpinan Pondok Pesantren Madinatul Ilmi DDI Siapo dan Pengajar buku Al-fatih, Wawancara Kantor Pondok Pesantren 18 Maret 2021.

Ridwan, Pengajar Buku Al-Fatih Pondok Pesantren Madinatul Ilmi DDI Siapo, wawancara, 18 Maret 2021. 
Al Bariq : Jurnal Pendidikan Bahasa Arab, 2, (2), 2021,

Ridwan, Pimpinan sekaligus Pengajar Metode Al-fatih, Kantor Pondok Pesantren wawancara, 18 Maret 2021.

Rosalin, E.,Gagasan merancang pembelajaran kontekstual (Bandung: Karsa Mandiri Persada, 2008)

Samsul Maarif, Al-munir Pesantren Annur pakis,cetakan Juni 2019.

Samsul Maarif, Tabel Nahwu PesantrenAnnur pakis, Cet. VII Juni 2020

Samsul Maarif, Tasrif danI'lal,Pesantren Annur pakis. Cet. VI Agustus 2019

Tiara Wulandari, Santri Pondok Pesantren Madinatul Ilmi DDI Siapo wawancara, Gazebo Depan Pondok Pesantren,23 Maret 2021.

Ulin Nuha, M.Pd.I.,Ragam Metodologi dan Media Pembelajaran Bahasa Arab (Banguntapan Yogyakarta: Diva Press 2016)

Van Hoeve, Ensiklopedia Islam, ( Jakarta:

PT. Ichtiar Baru, 2000)

Winarto Surahmad, Pendekatan dalam Proses Belajar Mengajar, (Bandung: PT. Remaja Rosdakarya, 1999) 